\title{
B.R:A
}

Instructions for authors, subscriptions and further details:

http://brac.hipatiapress.com

\section{List of Reviewers}

Date of publication: February $3^{\text {th }}, 2014$

To cite this article: (2014). List of Reviewers. Barcelona, Research, Art, Creation, Vol 2(1), 136. doi: 10.4471/brac.2014.06

To link this article: http://dx.doi.org/10.4471/brac.2014.06

\section{PLEASE SCROLL DOWN FOR ARTICLE}

The terms and conditions of use are related to the Open Journal System and to Creative Commons Attribution License (CC-BY). 
BRAC - Barcelona Research Art Creation. Vol. 2 No. 1, February 2014, p. 136

\section{List of Reviewers}

The editors of the Barcelona Research Art Creation, we wish thank the reviewers for their contributions to the quality of the journal during 2013.

Agustí, Eugènia

Àlex Nogué Joan Descarga Miquel Planas

Editors

Berenguer, José

Boncompte, Conxita

Dahó, Marta

de Laiglesia, Juan Fernando

Fusté, Jaume

Garí, Clara

Hernández, Fernando

Herranz, Yolanda

Martí, Antònia

Puig, Eloy

Valera, Alberto

Vaz, Oriol

Vela, Alicia

Velilla, Carlos

Vila, Antònia 